\title{
Contemporary Aboriginal Art from Australia's Desert: Context, Debates, and Analysis
}

\begin{abstract}
Aleksandra Łukaszewicz Alcaraz
The interest in Aboriginal art in Europe and in the whole Western world has grown exponentially since the late 1980s. Larger and smaller, more and less prestigious institutions and galleries are staging Aboriginal art, trying to simultaneously remove it from the ethnographic field, and introduce it into the global art market. Visual accordance between Aboriginal art-especially acrylic paintings from the Desert - and Western modernist painting makes the former desirable objects on the art market, but it also leads to laziness in learning about their real meaning within Aboriginal culture as well as to debates on their artistic and anthropological significance, interpretations, and values. In this article, I briefly present ongoing debates on the artistic character of Aboriginal artefacts and the aesthetic values of Aboriginal paintings from the Desert, in order to argue that the specific conditions of the painting production process should be considered in their interpretation. These conditions have their roots and explanations (I prefer narratives here) in Aboriginal traditions related to the Dreamtime, that is, their mythical past in which their ancestors created the land, which is not past history, but the continuous past-present influencing contemporary forms of life. I will address four important features of acrylic paintings from the region of the Desert. First, the change of medium - from coloured sand in the desert, to acrylic painting on canvas laid on the ground. Second, the realistic character of representing landscape in the form of painted topographic maps. Third, the importance of the use of traditional images and stories, and the simultaneous impossibility of using sacred images and symbols, which develops the discussion about the originality of Aboriginal paintings. Fourth, the collective method of artistic work. These issues are broadly discussed in Australian artistic research. However, they are sometimes overlooked in Western presentations of Aboriginal art. Our understanding of Aboriginal art should not devalue it by forcing it into our ready Western concepts of art, for example, those of modernist painting. Instead, we should explore its histories more deeply and examine Aboriginal within its own context
\end{abstract}

\section{Introduction}

Aboriginal contemporary art in Australia is simultaneously old and new. Its roots reach into the ancient past of the Dreamtime. Elaborated in a specific way nowadays, it brings delight to people around the world; at the same time, there are problems in its interpretation developed within and by the Western world. Interest in this art has been growing since 1971, when the Papunya Tula art movement was born. Its popularity increased in the late 1980s, with the first largescale appearance in the United States being the exhibition Dreamings. The Art of Aboriginal Australia, held in the Asia Society Galleries in New York City from October 6 to December 31, 1988. The exhibition combined major types (genres) of Aboriginal art, presenting mostly bark paintings and sacred sculptures from the

"Faculty of Painting and New Media, Academy of Art in Szczecin, Poland. 
Cape York Peninsula and acrylic paintings and shields from the Western Desert region of Central Australia. It was recognised as "a milestone for Australian Aboriginal art and coming-of-age in the representation of peoples of colour."1 It was also well received by the public, whose interest continues to grow in the horizon of postcolonialism and transculturalism in the contemporary global and mobile world.

An earlier exhibition that could also be mentioned is: "Primitivism" in 20th Century Art: Affinity of the Tribal and the Modern," displayed at MoMa in New York in 1984. However, as Beatrice Persson reveals in her research on contemporary Aboriginal art, this exhibition presented Aboriginal art as still primitive, and not as contemporary. It juxtaposed Aboriginal 'primitive' - or, as I prefer, tribal works of art with Western modernist works to highlight "the affinity between modern art and primitive aesthetics (...) show[ing] (...) how modernist art had been influenced by non-Western works of art."2 Another important exhibition was "Magiciens de la terre" held in Paris at the Centre Georges Pompidou and the Grand Halle at the Parc de la Vilette in 1989, presenting Western and non-Western artists side-by-side, where Aboriginal paintings were also present. The curator Jean-Hubert Martin specifically set out to do away from ethnocentrism, although debates arose if he managed or not. These exhibitions show the growing interest in Australian Aboriginal art, which belongs to non-Western culture that gains great interest nowadays - I do not think about ethnological investigations, but about interest in contemporary cultural and artistic development and values of non-Western societies.

The growing popularity of Aboriginal art in Australia and in the Western world has raised, as mentioned above, many discussions considering its artistic or ethnographic status: whether we should talk about works of art or artefacts, ${ }^{3}$ how to understand its cultural background, ${ }^{4}$ how to appreciate its aesthetic values, ${ }^{5}$

1. Francine Farr, "The Art of Aboriginal Australia," African Arts 22, no. 3 (May, 1989), 84-85.

2. Beatrice Persson, In-Between: Contemporary Art in Australia. Cross-culture, Contemporaneity, Globalization (Goteborg: Goteborg Acta Universitatis Gothoburgensis, 2011), 19191920.

3. See for example, the discussion between Denis Dutton and Arthur Danto on art and artefact and on Dutton's critiques of Danto's philosophical experiment with Pot People and Basket People - Denis Dutton, "Tribal Art and Artifact," The Journal of Aesthetics and Art. Criticism 51, no. 1 (Winter 1993), 13-21. Danto's argument was developed in: Arthur C. Danto, "Artifact and Art," contribution to the exhibition catalogue for ART/artifact (New York: Center for African Art, 1988), 18-32.

4. Howard Morphy, "On representation of ancestral beings," in Animals into Art, ed. Howard Morphy (London: Unwin/Hyman, 1998), 144-160; Morphy, Ancestral Connections: Art and an Aboriginal system of knowledge (Chicago: University of Chicago Press, 1991); Morphy, "Encoding the Dreaming - A Theoretical Framework from the Analysis of 
and how to decide what is an "authentic" Aboriginal work of art versus an "inauthentic" one. ${ }^{6}$ Many of these critical discussions have appeared as a series of cases, broadly discussed in literature and popular media, to which I refer further on in the article. In the following pages I will address these debates, focusing on contemporary Aboriginal painting from the Desert in Australia. These paintings are a focal point for all the issues mentioned above.

To propose a deep analysis of them, which attempts to retain their cultural and aesthetic sense and meaning, I enter into discussion with various theorists, among them Howard Morphy, Dennis Dutton, Arthur Danto, Joseph Margolis, Barbara Glowaczewski, and Elizabeth Burns Coleman.

\section{The Beginnings of Contemporary Aboriginal Painting from the Australian Desert: From Sand to Acrylic Paint}

Aboriginal contemporary art originated in 1971 at Papunya, a government settlement 260 kilometres northwest of Alice Springs, which is strikingly beautiful desert country flanked by two hills - one of which is Papunya Tula, an important Honey Ant Dreaming site shared by Aboriginal tribes in the Central Australian Desert. ${ }^{7}$ Geoffrey Bardon came there from New South Wales to take up a teaching position at the school and had noticed children drawing specific designs in the sand. He motivated the children, and later also the elders, to start drawing these designs, first on walls and small boards, and subsequently on canvas with acrylic paint, giving rise to the Papunya art movement that included mostly people from the Luritja and Pintupi language groups, but also from the Anmatyerr, Warlpiri, and Kukatja groups.

The impetus of the movement was very strong. Over six hundred and twenty paintings were produced in the first historic year, including the famous painting of the Honey Ant Dreaming on the Papunya School wall painted by Aboriginal elders, among them Billy Stockman Tjapaltjarri and Long Jack Phillipus Tjakamarra. Today, there are more than a hundred artists painting in Papunya and in various settlements scattered westwards, because following the Land Rights Act from 1975 the land west from Papunya was

Representational Processes in Australian Aboriginal Art," Australian Archaeology no. 49 (December, 1999), 12-22.

5. Elizabeth B. Coleman, "Appreciating 'Traditional' Aboriginal Painting Aesthetically," The Journal of Aesthetics and Art Criticism 62, no. 3 (Summer 2004), 235-247.

6. Coleman, "Aboriginal Painting: Identity and Authenticity," The Journal of Aesthetics and Art Criticism 59, no. 4 (Autumn, 2001), 385-402; Ross Bowden, "What Is Authentic Aboriginal Art?," Pacific Arts no. 23/24 (July 2001), 1-10.

7. Gabriele Pizzi, "Contemporary Aboriginal Desert Paintings," in Catalogue for the exhibition shown at the Plimsoll Gallery, Painting from the desert. Contemporary Aboriginal paintings (Tasmania: University of Tasmania, Centre for the Arts, 1990), 4. 
returned to its original owners, who have often moved back there from Papunya. Some other communities painting in Central Australia are Yuendumu, a primarily Warlpiri settlement three hundred kilometres northwest of Alice Springs; the Balgo Hills, situated on the edge of the Great Sandy Desert; and Alywarre and Anmatyerre women from Utopia, two hundred and forty kilometres northeast of Alice Springs. ${ }^{8}$

Aboriginal paintings from deserted Central and Western Australia have a complex background. They are based in ceremonial ground designs elaborated during rituals, for instance, in rituals of initiation which are traditionally realised with an accompaniment of chanting and dancing. Together, the varied actions play the performative function of invoking Ancestral Spirits and passing (in this example) the initiate into maturity. ${ }^{9}$ But contemporary Aboriginal art would not have been able to come into existence without the oppressed history of Aboriginals in Australia who - thanks in part to Geoffrey Bardon's sensibility and dedication - have started to recover their own culture and practices, transforming them according to new social and economical conditions. This does not mean that contemporary Aboriginal art in general, or Aboriginal painting from Australian deserts, are the same as their ritual antecedents. Aboriginal paintings on canvas are relatively new phenomena, despite the long history underwriting them.

\section{Modernist or Realistic Aboriginal Paintings?}

Aboriginal paintings from the Australian Central Desert are elaborated with dots in concentric circles and other forms invoking the desert landscape. These paintings have a flickering character, shimmering like sand and stones

8. Ibid., 7.

9. Ibid., 4-5: "Ground paintings vary considerably in dimension and structure and they have been known to measure up to a hectare in size. Their execution is complex and intensely ritualistic and is rarely witnessed by the uninitiated. The ground is first flattened by tribal elders after which a traditional blood letting is performed, and then as the young initiates gather close the intricate and deeply spiritual ceremony unfolds. The earth is often moulded three dimensionally after which the ground design is slowly executed. Natural ochres of various colours, mixed with wild desert cotton are dotted across the surface of the ground, forming a mosaic of half circles, circles, dots, and wavy lines. The chanting of the accompanying song cycles reveals the innermost core of Aboriginal law to the young initiates who have at this stage been deemed sufficiently mature and responsible to receive the sacred knowledge, to guard it and to transmit it to the next generation when considered opportune. The shuffling, stomping feet of dancers moving across the sand obliterates the ground design but as in all Aboriginal ceremonies and also in Aboriginal art the importance lies in the execution. Material permanency is not a traditional Aboriginal concept but it is through regular ritual performance that the Ancestral Spirits are invoked, so assuring cultural perpetuity." 
in the burning sun. Their visuality reminds one of abstract painting, but the formal, superficial resemblance to modernist paintings of the $20^{\text {th }}$ century causes many problems in the process of interpretation. On one hand, some art critics claim, like Kay Larson in 1988 in New York Magazine, that:

"[m]odernism has allowed us to comprehend the Aboriginal point of view... Aboriginal art at its best is as powerful as any abstract painting I can think of. I kept remembering Jackson Pollock, who also spread the emotional weight of thought and action throughout the empty spaces of his canvas."10

The visual similarity between modernist and Aboriginal painting should not however make us impose Western categories on non-Western art, aesthetics, and attitude. ${ }^{11}$ Different cultures enjoy different worldviews, histories, conditions, and contexts, so their concepts, ideas, and images are rarely fully compatible. Some similarity found between art of for example Pollock and Tjapaltjarri should not drive us to easy conflation of their styles, and blind us to the different modes of production of their works and the different sets of symbolic meanings in which their works are embedded.

The fact that Aboriginal paintings from the Desert are close to a Western modern aesthetic sensibility should not lead to the assumption that Aboriginal artists have the same forms of expression as modernists, or that the meaning of Aboriginal art can be interpreted fully within the tradition of modernism. As Beatrice Persson aptly states,

"the incorporation of indigenous art on the basis of form alone neglected its history, as well as the contemporary significance of its cultures of origin, which still very much is the case."12

To conform to two demands in one moment - the recognition of Aboriginal works of art as pertaining to fine arts, and the recognition of cultural specificity and meaning of these works - is very challenging. For example, the exhibition at the Zamek Cultural Centre in Poznań, Poland, Signs and Traces. Contemporary Aboriginal Art curated by Karolina Leśniak, presented works of such artists as Emily Kame Kngwarreye, Johnny Warangkula Tjupurrula, Clifford Possum Tjapaltjarri, Turkey Tolson Tjupurrula, and Don Ellis Tjapanangka, all the paintings from the Australian Desert came from the Dutch collection of Leslie

10. Kay Larson, "Their Brilliant Careers," New York Magazine (4 October 1988), 148-150.

11. I argue against the imposition of European categories on Non-European art on the example of contemporary South African art and its relation to European Avantgarde and avantgarde art - Aleksandra Lukaszewicz Alcaraz, "Can We Talk about Contemporary Avant-garde outside Western Cultures? The Case of Contemporary Art in the Republic of South Africa," Art Inquiry. Recherchers sur les arts 19, no. 28 (2017), 171-185.

12. Persson, In-Between: Contemporary Art in Australia, 18. 
Smith Gallery (now Smith Davidson) in Amsterdam and were shown without their original titles. They were only given numbers, thus depriving these paintings of any meaning other than that associated with modernist Western abstraction. The lack of direct descriptions of the maker and his or her painting supposedly helped visitors to focus on the works' aesthetic and artistic qualities. This lack was mitigated by boards (panels?) with information on Aboriginal history and culture, but they still left the impression that more information or explanation was still needed, for example on how to connect the paintings with their background that obviously condition (or shape) their meanings. Fortunately, the exhibition catalogue, Signs and Traces. Contemporary Aboriginal Art, contains some theoretical and historical discussions on Aboriginal painting in Australia, along with short descriptions of the selected major Aboriginal painters. ${ }^{13}$ Despite these, however, the direct relation between the painting and the Australian landscape to which it is intimately related was gone. The geo-specifity of the painting was lost in translation. Unlike their alleged Western counterparts, Aboriginal paintings from the Desert are not in fact abstract. They are often strongly representational, but within a different order of representation, unfamiliar to the West. While representing landscape they have topographic perspective, similar to a map made with shining dots and rounded forms, which reflects to a high extent the impression of looking on the deserted land with its sand, stones, holes, and snakes, which in the strong sun flickering in the eye gains and loses precise forms, transforming the landscape and maintaining it through the internal movement.

Trying to fit Aboriginal art into Western categories used in artistic and philosophical discourse is just one more example of Western hegemony. Examining this relationship critically and acknowledging that the dominant culture's discourse is very often unaware of this unequal relationship even when acting with good intent to recognise and argue for the value of Aboriginal painting, one concludes that the modernist lens is ineffective in trying to grasp the specificity of these paintings.

13. Signs and Traces. Contemporary Aboriginal Art 2015 [exhibition catalogue] (Poznań: ARTYKWARIAT, 2015). 
Picture 1. Ngupulya Pumani, Maku inmaku pakani, 2014. Synthetic polymer paint on canvas. Molle Gowing Acquisition Fund for Contemporary Aboriginal Art, 2014

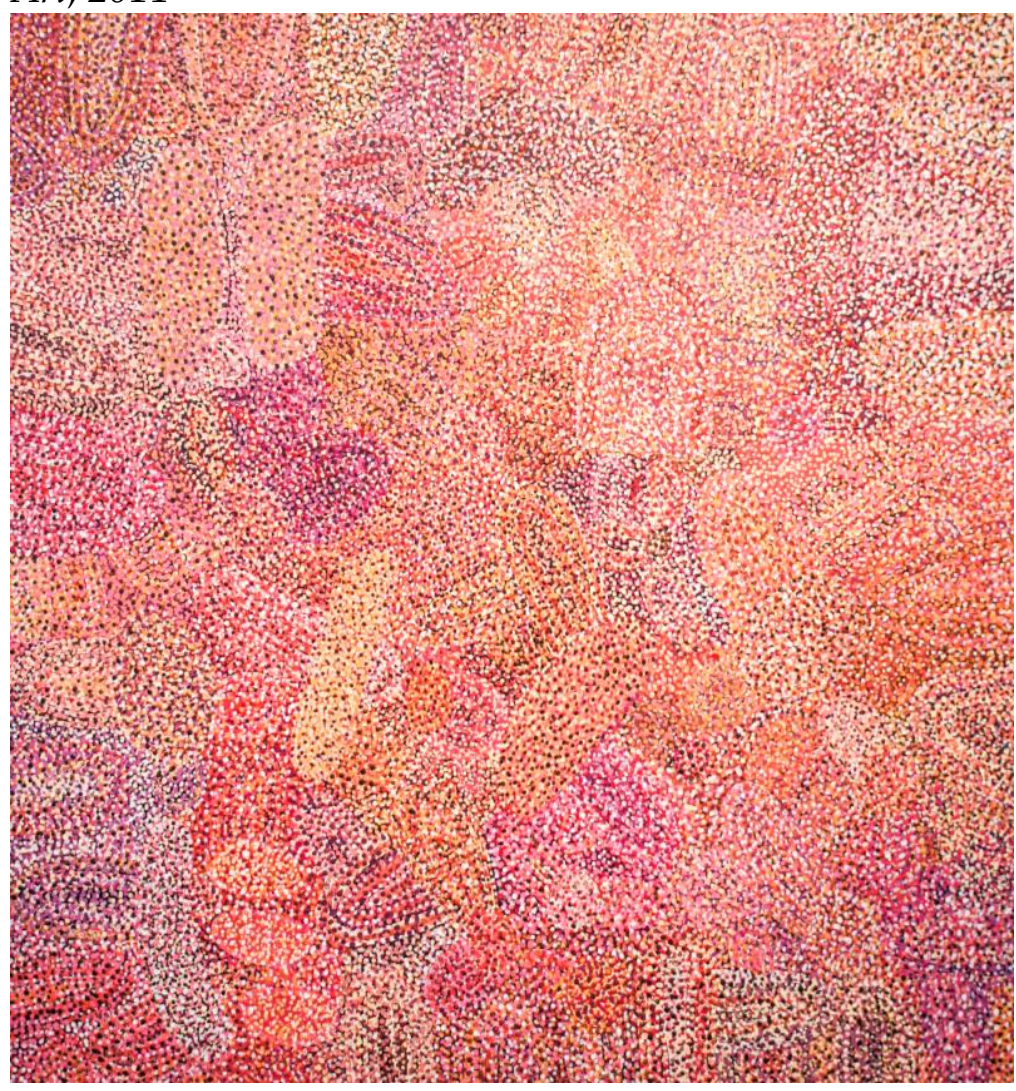

Source: Aleksandra Łukaszewicz Alcaraz.

\section{A Work of Art or Artefact? Artistic Status of Aboriginal Paintings and Their Aesthetic Qualities and Originality}

The specificity of Aboriginal art has generated various discussions on its interpretation on different levels: artistic, anthropological, and cultural. On an artistic level, the predominant issue regards the status of Aboriginal art as 'fine art' and the aesthetic qualities of Aboriginal paintings.

\section{A Work of Art or an Artefact?}

Denis Dutton presents some interesting considerations on the question of if and when we should interpret the indigenous art object as an artefact, and when as a work of art. His argument encompasses a widespread range of nonWestern traditions, not limited to Aboriginal art from Australia, or even to his major point of inquiry into indigenous tribal art from the Sepik region in 
Papua New Guinea. The American philosopher and evolutionary aesthetician attempts as his major objective to determine whether it is possible to use aesthetic criteria in evaluating indigenous art, and argues against Arthur Danto's claim that the traditions of art and utilitarian artefact are indiscernible. ${ }^{14}$

Dutton exposes how Danto takes indigenous perception and understanding as irrelevant to the aesthetic appreciation of the object; it is on this basis that Danto claims that there is no perceptible difference between a tribal work of art and an artefact. Danto's exercise with a little (supposedly Western) girl who perceived no difference between works of Pot People and Basket People - both tribes produce pots and baskets, but Pot People endow their pots with rich symbolic significance, while Basket People do not do the same with their baskets - ignores important questions such as: "Did the object move its makers? Is it a good one in the tribe's eyes? Is it a piece of special spiritual significance? Is it a purely utilitarian object? A piece of tourist kitsch?"15

Dutton argues that indigenous works of art are not indiscernible from indigenous artefacts ${ }^{16}$ and that a competent viewer can detect inherent formal qualities of excellence together with their meaning, such as aesthetic perfection, superior medium or material used, and so on. For example a specific way of elaboration can indicate that the object was created with a spiritual meaning and not with an utilitarian one, as Dutton shows in a philosophical experiment involving the Jungle People and the Tourist People - clearly an analogue to Danto's Pot People and Basket People. The Jungle People, who produce carvings for ritual ends, and the Tourist People, for sale to tourists. ${ }^{17}$ It is very probable that the competent viewer discerns a ritual object from a tourist commodity, because of the type of material, details of elaborations, level of workmanship visible in the form, because it is differently made. These observations show how different contexts and different means drive the carvings made by Jungle People and Tourist People - sacred and economic - providing their meaning. This leads Dutton to understanding that aesthetic perception is embodied and conditioned culturally, an so discards the claim of indiscernibility between art object and artefact.

Danto's argument on the perceptual indiscernibility between a work of art and a work of non-art has also led to other polemics, such as an excellent

14. Dutton, "Tribal Art and Artifact," 17.

15. Ibid., 15.

16. For Dutton also the comparison by Danto of a tribal work of art and an artefact to the famous case of Warhol's The Brillo Box is wrong, because Warhol's piece is parasitic on an everyday object, which is not the case with a tribal work of art. Tribal art can be differently connected to quotidan objects and discernible from them - Dutton, "Tribal Art and Artifact," 15.

17. Ibid., 16. 
one by Joseph Margolis: Margolis shows that the argument for perceptual indiscernibility is based on purely sensory data, simplistically, like a fruit fly's senses. Margolis argues against Danto often, but his sharpest criticism against perceptual indiscernibility is developed in his 1998 article, "Farewell to Danto and Goodman." According to Margolis, the ontology of a work of art is based neither on just matter, nor is it purely conceptual (as Danto believed); it is instead complex and hybrid. Works of art are intentional entities, physically embodied and culturally emergent, and their qualities are perceptible, though not always reducible to sensory data. ${ }^{18}$ Viewing the work of art, we not only know that it is a work of art, but we see the work of art itself, and not just a box for washing powder, a pot, or a coloured piece of material. Intentional properties of cultural entities are perceivable, though non-sensory. ${ }^{19}$ For Margolis Intentionality is the interpretability, the quality of having some meaning, place in the discourse, which appears with the invention and development of language ${ }^{20}$ This quality demands materiality, but is not reduced to what it best shows, a process of aesthetic judgement described by Roman Ingarden in his phenomenological aesthetics. According to Ingarden we come to perceive meaning and aesthetic values of the work of art stemming from material objects, which initiates the aesthetic experience having its contemplative and reflective moments. Then we see a work of art such as Venus de Milo and not just a piece of marble shaped specifically. ${ }^{21}$ Margolis goes further than Ingarden and talks about not only works of art, but about different cultural entities, such as various institutions and identities. The meaning of the institution is not the same as of that of blocks, and the meaning of identity is not the same as material body (though it is embodied). Then, as Margolis shows, any refusal to admit that we see a work of art rather (as opposed to) than a non-art object would:

"drive us to say that we never see anyone's doing anything, we see no more than 'bodily movement' (or, sense data answering to them), which we imaginatively invest with the intentional features of human actions. If that were true, we should

18. Joseph Margolis has developed this view in many of his writings, for example: Joseph Margolis, "Works of Art as Physically Embodied and Culturally Emergent Entities," The British Journal of Aesthetics 14, no. 3 (1 March 1974), 187-196; Margolis, What, After All, Is a Work of Art?: Lectures in the Philosophy of Art (University Park: Pennsylvania State University Press, 1999); Margolis, The Arts and the Definition of the Human: Toward a Philosophical Anthropology (Stanford: Stanford University Press, 2008).

19. Margolis, "Farewell to Danto and Goodman," British Journal of Aesthetics 38, no. 4 (October 1988), 369.

20. Margolis, "Intentionality, Institutions, and Human Nature," The Monist 69, no. 4 (October 1986), 546-567.

21. The whole description of aesthetic experience you can find in: Roman Ingarden, Studia z estetyki 1 (Studies in aesthetics 1) (Warsaw: PWN, 1957). 
never hear speech: we should hear no more than sound."22

Luckily, we do not perceive just sensory data, but we hear meaningful voices, we see persons, meaningful gestures, and works of art. Our perception is embodied and synthesising, making sense out of the world, and this dimension cannot be separated into mind and matter. Then we may perceptually differentiate between artefacts and artworks, if we are competent and know the context well enough. Of course we have to remember that to be a work of art outside Western culture does not necessarily mean to be art for art's sake. The pure non-functional ideal of art was created in $18^{\text {th }}$ century in Europe and later it was hegemonically imposed on other cultures with other definitions of art that include usefulness, ornamentation, ritual purposes, etc.

Although Dutton, like Margolis, rejects Danto's argument on perceptual indiscernibility, he preserves Danto's differentiation between the work of art and the artefact based on systems of means and ends into which they fit. Dutton repeats after Danto that art objects are a compound of thought and matter, and that: "[t]o be a work of art (...) is to embody a thought, to have a content, to express a meaning, and so the works of art that outwardly resemble primitive artefacts embody thoughts, have contents, express meaning, though the [artefacts] they resemble do not." 23

\section{Aesthetic Qualities of Aboriginal Paintings}

Examining the artistic character of Aboriginal paintings and asking about their aesthetic qualities is often confined to the Kantian perspective without reference to their original meanings and modes of production. This approach to Aboriginal paintings supports and conditions the recognition of Aboriginal paintings as works of art from the universalistic, transcendental point of view. The reasoning for this perspective is broadly presented in the publications of Elizabeth Burns Coleman, who claims that in order to claim Aboriginal art as art in a strict sense, we have to recognise the works' aesthetic qualities, without referring to the cultural and spiritual dimension.

"[T]he Aboriginal values that people suggest should be used as the standards for judging classical Aboriginal art are either based on a religious knowledge system that is not open to most non-Aboriginal people or are not aesthetically relevant."24

22. Margolis, "Farewell to Danto and Goodman," 370.

23. Danto, Beyond the Brillo Box: The Visual Arts in Post-Historical Perspective (Berkeley: University of California Press, 1998), 112.

24. Coleman, "Appreciating 'Traditional' Aboriginal Painting Aesthetically," 238. 
However, I do not agree with the above argument, as this version cuts off cultural embededness in favour of contemplating aesthetic beauty in the Kantian model of disinterestedness. This claim is not so strongly defended in Coleman's paper, and she seems to wobble on the line between acknowledging the importance of culturally fixed identity of Aboriginal paintings and discarding them from the aesthetic point of view. She does not want to overemphasise the stylistic resemblance of Aboriginal paintings to Western abstract art, but at the same time she states that we should appreciate these works from a broader perspective than that of solely Aboriginal political and moral values..$^{25}$

Coleman's problem seems nonetheless to be bound too tightly to a Kantian and analytic philosophical tradition, precluding aesthetics in a broader sense that embraces all the senses and embodied consciousness. This broad understanding, in explicit discord with Kant's view, is advocated by Arnold Berleant - not resigning from sensible, visual experience, but not limiting aesthetic feeling to it. In place of disinterestedness, Berleant proposes the aesthetics of engagement, ${ }^{26}$ that interpenetrate each other, thereby enriching human aesthetic experience. Having an aesthetic experience is not just about a visual pleasure. 'Aesthetic' derives from the Greek word aisthēsis, which means perception from the senses, and it involves the whole human being, together with his/her consciousness. Approaching aesthetic experience from this stance allows us to think about paintings from the Desert as perceived and evaluated aesthetically without cutting them off from their Aboriginal meaning, modes of production, and dissemination.

Dutton's, Margolis', or Berleant's approach to aesthetics makes it much easier to argue that Aboriginal art is simultaneously aesthetically valuable and culturally meaningful, and that these values are intermingled in the aesthetic experience.

\section{Other Interpretative Problems with Originality of Aboriginal paintings from the Desert}

Omitting the obstacle of trying to impose Western categories on Aboriginal painting, we may easily stumble over another problem in trying to essentialise Aboriginal contemporary painting, binding it too strongly with Aboriginal heritage and not allowing for any reconceptualisation of it, even by Aboriginals themselves. Barbara Glowaczewski examines this issue, showing that we should abandon myths of both "the good savage" and "the primitive

25. Ibid., 246.

26. There are many books in which Berleant discusses the aesthetics of engagement, but an essential one is: Arnold Berleant, Art and Engagement (Philadelphia: Temple University Press, 1993). 
cannibal" in relation to indigenous peoples. On the basis of her long-term research on Aboriginal people in Australia and cross-cultural analysis, she claims that "[a]mong the most pressing needs today is the need to accept everyone's right to redefine their cultural identity," and that only after this step is it possible to proceed with "proper analysis of the relationship between Aboriginal cosmology and the environment" and Aboriginal art. ${ }^{27}$ This issue is of a great significance, because it tackles one side of the problem in the debate over the authenticity of Aboriginal art. Real Aboriginal art - some claim cannot differ too much from its original, traditional form, which comes from defining West as progressive and non-West as traditional and as a subject of concern to upkeep the heritage. Apart from recognizing that this mapping is not necessarily correct, we have to notice that real contemporary Aboriginal art is and cannot be the same as rituals and images, from which it emerged. Although, if the canvas shows forms and designs considered too secret or sacred, Aboriginal elders may protest fiercely against their being displayed to the uninitiated, as witnessed after the exhibition mounted in Alice Springs in 1971, when:

"Elders protested that custodial rights to paintings were being flouted by a number of artists. There were accusations of 'dream poaching' as artists were found guilty of painting Dreamings over which they had no authority or custodianship and were also depicting sacred mythological details that should only be accessible to initiated men. A meeting was called and it was decided to eliminate elements that were considered sacred and consequently unsuitable for the uninitiated."28

The line on which one walks therefore is therefore then is very thin, avoiding non-Aboriginality while equally protecting secrets of Aboriginal life and cosmology. Nevertheless, we should admit these difficulties in Aboriginal paintings and not try to dissolve them through the imposition of anthropological concepts of originality that, preventing change from the traditional medium to a new one, from secret or sacred designs to more secular forms, and from individual to participatory modes of production.

Aboriginal visual expression in paintings - from hectares of moulded ground covered with coloured sands, to acrylic paintings on canvas - is a move to which Aboriginal people are entitled. As the holders of their heritage, they are free and able to transform it according to their rules and needs. Canvas and acrylic paints have been chosen for their endurance and the relative ease of mobility of the images created with them. Thanks to this development, images

27. Barbara Glowaczewski, "Dynamic Cosmologies and Aboriginal Heritage," Anthropology Today 15, no. 1 (February 1999), 3-9.

28. Pizzi, "Contemporary Aboriginal Desert Paintings," 5. 
can be seen by more people than just the tribe in question ${ }^{29}$ the paintings can travel, be exhibited, and sold for the community's benefit. All are positive elements, allowing a broader audience to become acquainted with Aboriginal art and culture, and providing necessary funds to indigenous communities. I argue that this transformation should not be judged negatively as leading to allegedly 'inauthentic' art. The myth of authenticity should here be abandoned, although - as discussions in research literature, TV programmes, and other popular media demonstrate ${ }^{30}-$ it still is full of life, especially when we relate it to the art of indigenous cultures.

The acrylic paintings in the Central Desert region of Australia are painted in a way that is both traditional and non-traditional, constituting a way that is individually and collectively a meaningful transformation of both Western methods of elaborating paintings, and of traditional Aboriginal designs. The works are painted not on stretched canvas on a stretcher placed on an easel, but on canvas placed directly on the ground, without any stretcher. Painters kneel or squat on them, painting dots and forms, so that there is a kind of continuity of painting directly on the ground. This continuity in the mode of production experiences also a discrepancy, in that the ground is not moulded and used for the painting itself, but serves only as the support. This allows the canvas from to be taken from the ground and later placed on a stretcher, in order to make them portable and marketable. The fact that there is not only no stretcher but also no easel is connected with a different mode of perceiving the depicted reality. Renaissance painters started the Western tradition of painting with an easel, looking at the object of the study through the lens of geometric perspective (as described so precisely by Pierro della Francesca), ${ }^{31}$ which later also became the mode for photographic vision. The Renaissance's physiological or rational gaze came to overrule the medieval's more symbolic one. However, Aboriginal painters are not looking at the object straightforwardly, placed somewhere in relation to the horizon or vanishing point. Instead, they look to the ground - from a top-down perspective, a kind of topographic view depicting landscapes of their homeland by actually touching the ground.

The mode of production - loose canvas laid on the ground and painted in an aerial perspective by the person above it - is then very meaningful. It

29. Although the word 'tribe' in relation to Aboriginality spurs anthropological debates in mixed spirit of political correctness and post-modernism, Aboriginals themselves have reclaimed the word, rejecting its negative denotation of society without political structure - Glowaczewski, "Dynamic Cosmologies and Aboriginal Heritage," 3-4.

30. Much commotion was raised with an Australian television documentary report by Australian Broadcasting Commission (ABC): "Art from the Heart" (1998) and "Dot for Dollar" (1999).

31. Pierro della Francesca, De prospectiva pingendi. O perspektywie w malarstwie (De prospectiva pingendi. About the perspective in painting), ed. Ryszard Mirek (Kraków: Universitas, 2016). 
relates these paintings directly to their origin, but without equating them to the anthropologically authentic artefacts. It also shows the importance of contact with the earth as forming part of the artistic process, and testifies to serve as a clue to understanding the realistic character of these paintings, so that we stop treating them as mere abstract dotted patterns, flickering aesthetically in eyes of the viewer. The phenomena of touching and its connection to seeing is very important, for example, in contemporary paintings from the Balgo region in the Western Desert. ${ }^{32}$ Balgo contemporary painting originated from the Papunya Tula movement, after which original members of Papunya were allowed to diverge in the 1980s, as illustrated in Christine Watson's research. Watson explains how jabbing, knocking, and pattering during ceremonial rituals shows that touch cannot be disconnected from its visual and auditory side. This allows us to recognise the multisensorial nature of sign-making, ${ }^{33}$ for instance, in a work from 1990 by Donkeyman Lee Tjupurrula, "Yata Yata Tjarinpa, West from Lake Mackay" (1990), and Hector's Burton piece "Arumara Tjukurpa" (2011) where concentric, geometric but fluent forms in red, yellow, white, and black give a very strong plastic impression of three-dimensional topographically structured landscape space, which has tactile, atmospheric, audible, and fragrant characteristics.

32. Balgo contemporary painting originated from the Papunya Tula movement, after which original members of Papunya were allowed to diverge in the 1980s.

33. Christine Watson, "Dotykając ziemi. Ku estetyce współczesnego malarstwa Balgo" ("Touching the earth, towards the aesthetics of contemporary Balgo painting"), in Estetyka Aborygenow. Antologia (Aboriginal aesthetics. Anthology), ed. Monika Bakke (Kraków: Universitas, 2004), 128. 
Picture 2. Hector Burton, Arumara Tjukurpa, 2011. Synthetic polymer paint on canvas. Purchased with funds provided by the Aboriginal Collection Benefactors' Group 2012

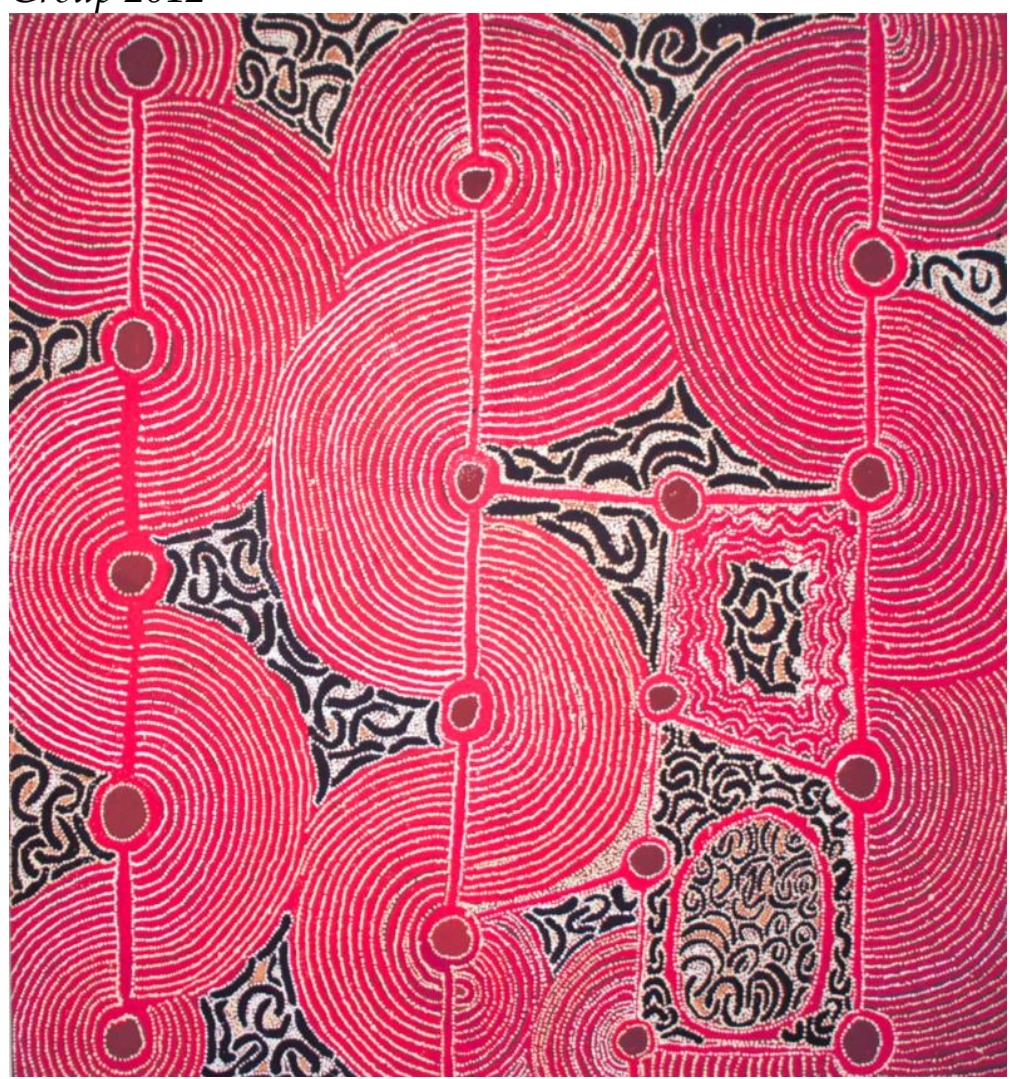

Source: Aleksandra Łukaszewicz Alcaraz.

Different Forms of Representation

What, then, are Aboriginal paintings about? Aboriginal paintings encode Dreaming in their dotted flickering forms and designs. Howard Morphy, one of the most prominent figures in researchers on Australian Aboriginal art in Australia (mostly being focused on a different region than I examine here, but not exclusively, on Arnheim Land) conjectures that in Australian Aboriginal art "referential meaning is primary (...) [and] partly explains its sacred nature." 34 The designs present in Aboriginal paintings are not just a spontaneous artistic creation, but originate from the Ancestral Beings, who in the mythological past travelled the land, creating the landscape with their actions. This mythical past is not just the past, it is not dead, on the contrary, it is ever - this is the mythical past come to life in the present, because if the Ancestral Beings were not active as forces in the landscape, the landscape would collapse, the waterholes and hills would disappear; as expressed, for example, in the painting by Tommy Watson

34. Morphy, "Encoding the Dreamming, 13. 
from Papunya (born c.1935) Wipu rockhole from the year 2004 (Il. 2). The painting covered with mostly red, white, yellow, and black dots organised in seemingly abstract forms - represents Watson's grandfather's country and the numerous rockholes to be found there, which were created together by the activity of an ancestral snake, who remains present as an unseen force within the land.

Paintings from the Desert are usually representations of the landscape from a topographic yet also symbolic birds-eye points of view. They are often made not as individual objects, but as sets formed according to two principles: "on the basis of their reference to a particular place or area, and on the basis of connection to some Ancestral track." 35 This is applicable in the case of paintings by Tim Leura Tjapaltjarri (c 1929-84) from Papunya, ${ }^{36}$ for example his Kooralia (from 1980) (Il. 3). The piece offers a view of Tjapaltjarri's birthplace in Napperby Creek, where "[a]ltering bands of colour show the ripples of sand in the creek bed, surrounding which are a number of other sites with varying topographies or vegetation," 37 but they also refer to Seven Sisters or Pleiades. However, the structure of the surface of the painting does not depict the appropriate actual scale of the actual spatial relationships between features of the landscape or rather the whole environment as the image also embraces the starry sky. As Morphy states, "Rather it encodes mythologically significant features of that landscape and affects the way the landscape is understood and perhaps even the way that it is seen."38

35. Morphy, "Encoding the Dreamming, 15.

36. Tim Leura Tjapaltjarri was born in Napperby Creek and grew up around Napperby Station in Anmatyerr country, to the northwest of Mparntwe (Alice Springs), but moved to Papunya with his young family in the late 1950s.

37. Description of the piece in the Gallery of New South Wales.

38. Morphy, "Encoding the Dreamming, 16. 
Picture 3. Tommy Watson, (b c 1935), Pitjantjatjara, Irruntju (Wingelina), Southern Desert region, Wipu rockhole, 2004. Synthetic polymer paint on canvas. Purchased with funds provided by the Aboriginal Collection Benefactors' Group

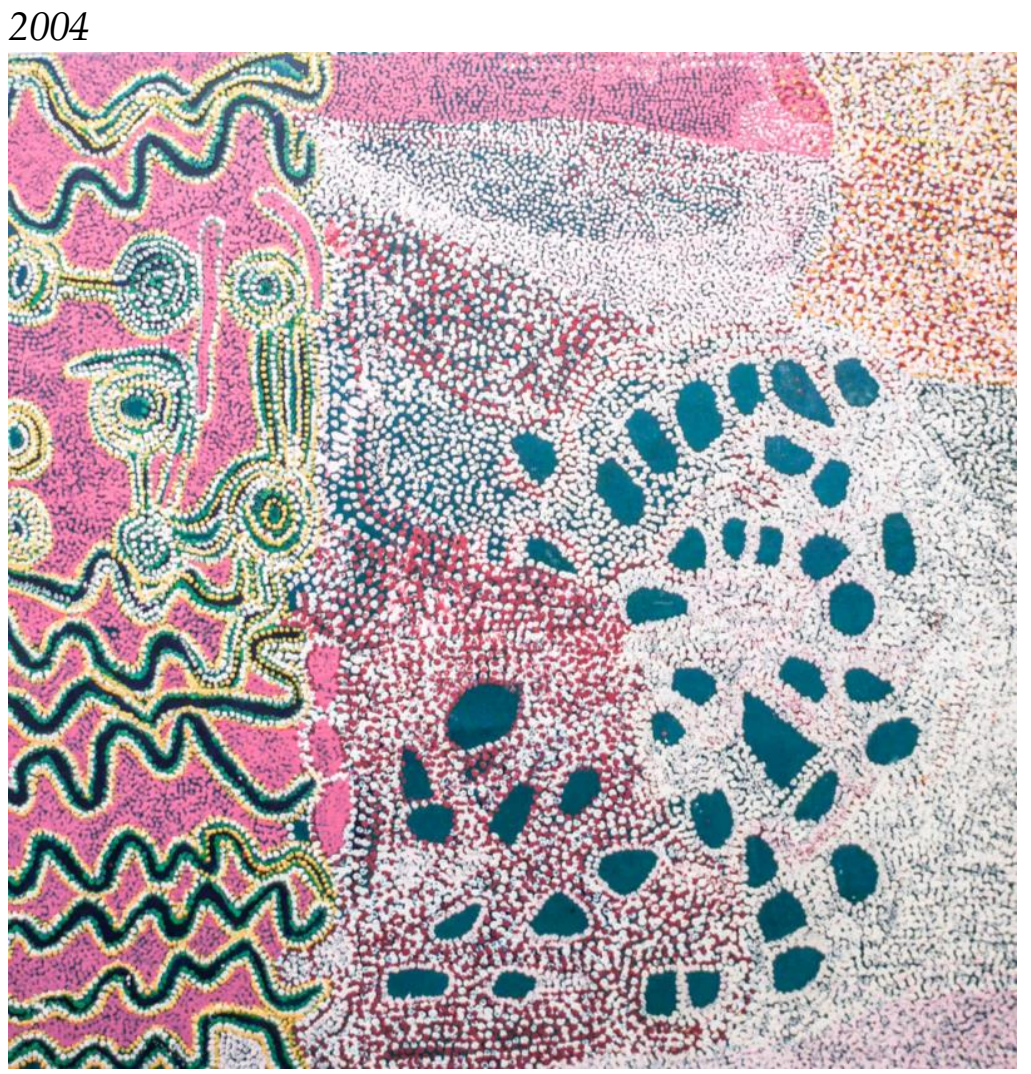

Source: Aleksandra Łukaszewicz Alcaraz.

\section{Sacred and Secular Designs}

In Aboriginal paintings, various forms provide means by which the designs are transformed and transferred from the sacred sphere to the secular. This transformation is multifaceted, as Francoise Dussart demonstrates exhibits in her research paper on Translations of Painting on the Body. The first transfer is a translation from mythic Dreamtime to designs and rituals, within which designs appear and play a function; these designs that appear here are on a body and on the ground. The second transfer is from a body and/or ground to canvas and acrylic paint: this transfer allows a social dialogue to develop with the world outside of the community by means of paintings, ${ }^{39}$ and also possesses much needed economic advantages has the advantage of profitability to the artists and to their settlements. The third transfer is from painting to film, which is described

39. Francoise Dussart, "Translacje malowidła na ciele" ("Translation of paintings on the body"), in Estetyka Aborygenów. Antologia (Aesthetics of Aborigines. Anthology), ed. Monika Bakke (Kraków: Universitas, 2004), 91. 
by Dussart in her article, also the documentary film titled: Warlukurlangu: Artists of Yuendumu. Here she considers work not created by Aboriginals themselves, but by a film maker with large experience in work with Aboriginal communities. Again we see evidence to support disembodying the painting on a body. ${ }^{40}$

Picture 4. Tim Leura Tjapaltjarri, (c 1929-1984), Antmatyerr, Papunya, Central Desert Region, Kooralia, 1980. Synthetic polymer paint on canvas. Gift of the Art.

\section{Gallery Society of New South Wales 1995}

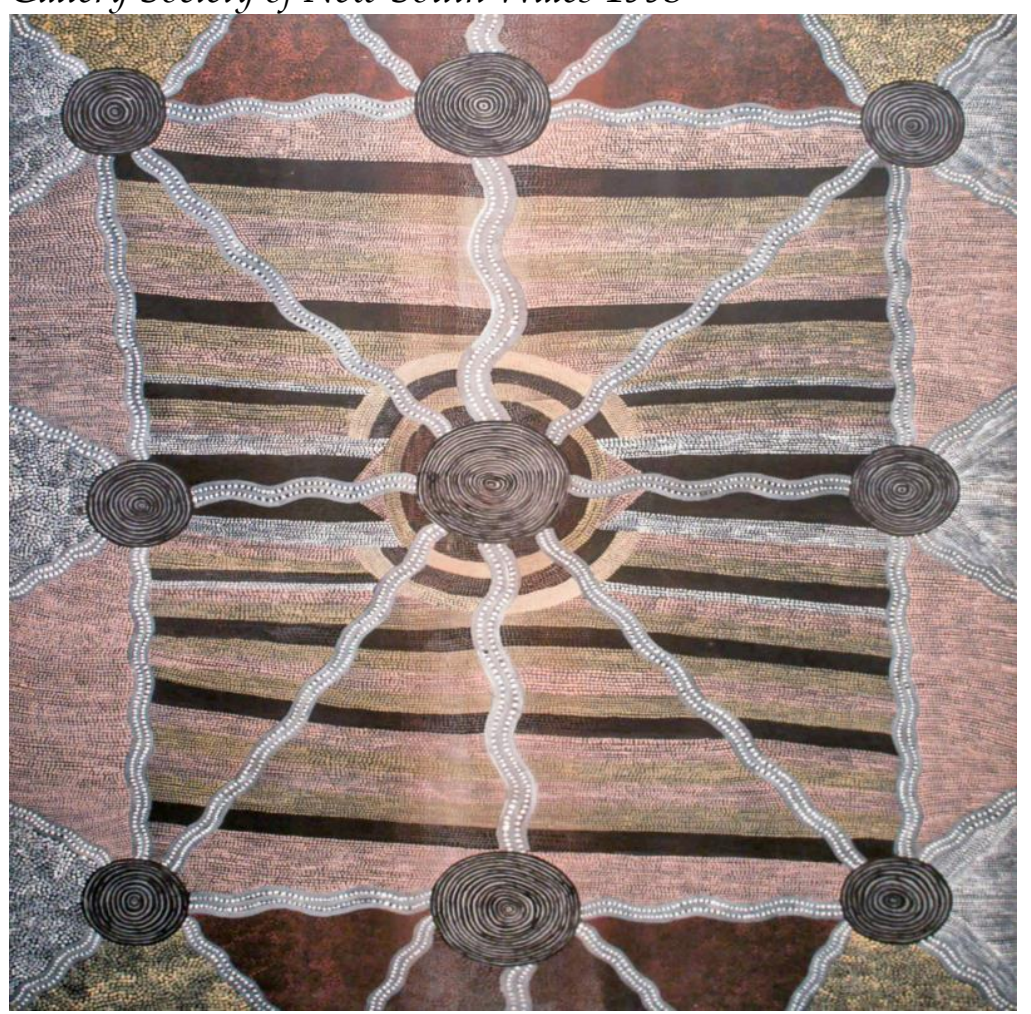

Source: Aleksandra Łukaszewicz Alcaraz.

In this process of transforming of the secret and sacred designs, what matters most is the authority of the person who creates the painting, and the intended purpose of the design or designs used. Many paintings are not done not for a ritual purpose, and thus do not have ritual power. Traditionally - for example, in the Warlpiri community - only men possessed the pertinent authority on ritual designs, in which forms and meanings are more difficult to negotiate, causing an obstacle for a for public display and dissemination of the designs outside the community; while women had access to more designs which were proper for the uninitiated. As a result, paintings made by Walpiri women had less restrictions

40. Ibid., 95. 
on sale than those by men. ${ }^{41}$ Also important to note is that in the late 70s, elder men passed to women elders the right to use the dotted background - which is an adaptation of birds' and plants' fluff, traditionally restricted to paintings on men's bodies. Since then, these forms can be used by both genders, for both commercial and non-commercial aims. ${ }^{42}$ For example, various artists from the community paint Dreamings like: Dreaming Fire (Molly Nampijnpa Langdon, 1984), Water Dreaming (painted by many, including: Leavannia Watson Nampijinpa), or Flying Ant Dreaming (Maria Brown Nampijinpa, 2018), with segments of iconography painted by women on bodies in the rituals and motifs that are adapted from designs painted by men.

The forms and designs of the secret and sacred sphere do not need to be reproduced in paintings in order to make them "originally" Aboriginal or "authentic." These paintings from the Desert, regardless of their intended public, are authentic and keep the connection with Ancestral paths alive. Contemporary Aboriginal artists have the opportunity to reshape their cultural heritage and should not be obliged to identify themselves in an essentialising, traditional way, a point of view fiercely defended by Barbara Glowaczewski. ${ }^{43}$ Glowaczewski decries the absurdity of an instant demand put on Aboriginals willing to take part in national development, that they should be identified in an Aboriginal way and they should formulate this identity in the form dictated by Whites. She decries the fact that "they are asked to prove their spiritual continuity with the land while being prevented from returning there." 44 Aboriginal people should be able to reconfigure their common future by participating in cultural and economic growth, and not be forced to prove some kind of ethnographic authenticity in contrast to debate on authenticity and originality held since the mid-1990s for about a decade.

\section{Participatory Mode of Production}

The controversies over authenticity that are a big part of contemporary discourses on Aboriginal art, also stem from the fact that Aboriginal artists very often collaborate with others or even sometimes sign works done by others. Famous cases that brought up this discussion on forgery and authenticity came strongly to the fore in the case of from Kathleen Petyarre (who received the 1996 Telstra Award for the work Storm in Atnangkere Country II, painted largely by her Welsh-born partner Ray Beamish) and Ginger Riley, the widely exhibited Northern Territory Aboriginal painter who acknowledges signing paintings brought by a group of Aborigines who received substantial gifts in cash and

41. Ibid., 93.

42. Ibid., 92.

43. Glowaczewski, "Dynamic Cosmologies and Aboriginal Heritage," 3-9.

44. Ibid., 5. 
similar in exchange. ${ }^{45}$ These issues have been discussed on in television programmes like documentary report "Art from the Heart" (1998) and "Dot for Dollar" (1999) by Australian Broadcasting Commission (ABC) which raised critical reflection.

While the focus point of the debate was again the concept of authenticity, as Elizabeth Coleman explains, this debate was laden with three untruths: "a false understanding of the nature of authenticity as tradition"; the myth of a precontact world and "unspoiled" natives; and the art/craft distinction. ${ }^{46}$ These untruths condition the belief that authentic Aboriginal art should be not evolve from its original form and function, and lead to accusations that this Aboriginal painting is often inauthentic. Nevertheless, we should keep in mind one more set of variables, namely that there is no singular agreed-upon definition of authenticity in art, and that there exist different definitions of it. Originality, authorship, ownership, and authority are just some of the elements by which we consider a piece as Western art or contemporary Aboriginal painting from Australia.

In Australia, an authentic painting is one realised by a person with authority over a Dream and designs connected to that Dream, or by other persons under the supervision of that authority. Ross Bowden acutely observes that:

"In Aboriginal societies traditionally, where paintings and other artworks were produced primarily for ceremonial display, an 'authentic' work was one done by a person, or at the request of a person, who 'owned' the motifs appearing in it. In Aboriginal societies traditionally visual images, as well as myths and even rituals, were typically owned by particular groups - though rarely if ever by individuals and only members of a group that held copyright to an image had an automatic right to reproduce it, or to authorise its reproduction." ${ }^{47}$

\section{Conclusion}

Superficial perception of Aboriginal paintings misses the point and does not permit full understanding of their richness. The trial to confirm the status of contemporary Aboriginal paintings from the Australian Desert as pertaining to fine arts, by means of denying the recognition of their cultural significance, both demonstrates the dominance of the Western perspective, and is futile in approaching their meanings and values, unless we broaden and decolonise the definition of art. It is important to gain knowledge about the modes and

45. Bowden, "What Is 'Authentic' Aboriginal Art?," 2-7.

46. Coleman, "Aboriginal Painting: Identity and Authenticity," 386.

47. Bowden, "What Is 'Authentic' Aboriginal Art?," 7. 
conditions of production of these paintings in order to fully understand and appreciate them.

I would like to conclude by reiterating three critical pathways to move beyond the present impasse on Aboriginal art. The first one directs us to necessary recognition of the cultural embededness of contemporary Aboriginal art, without reducing it to the status of a set of artefacts understood ethnographically. The second, taking up a post-Kantian view as proposed in aesthetics of engagement presented by Berleant, who shows perceptual, environmental and social rootedness of aesthetical values, and prevents us from overemphasising the stylistic resemblance of Aboriginal paintings to Western abstract art in order to appraise them aesthetically.

We can appreciate Aboriginal paintings considering also political, moral, and cultural conditions, without losing the aesthetic value - if we get rid of Kantian disinterestedness. As Elizabeth Coleman put it: we should search "for criticism that is 'more attuned' with Aboriginal cultural standards and values." 48

\section{Bibliography}

Berleant, Arnold. Art and Engagement. Philadelphia: Temple University Press, 1993.

Bowden, Ross. "What Is Authentic' Aboriginal Art?." Pacific Arts no. 23/24 (July 2001), 1-10.

Coleman, Elizabeth B. "Appreciating 'Traditional' Aboriginal Painting Aesthetically." The Journal of Aesthetics and Art Criticism 62, no. 3 (Summer 2004), 235247.

_. "Aboriginal Painting: Identity and Authenticity." The Journal of Aesthetics and Art Criticism 59, no. 4 (Autumn, 2001), 385-402.

Danto, Arthur C. Beyond the Brillo Box: The Visual Arts in Post-Historical Perspective. Berkeley: University of California Press, 1998.

_. "Artifact and Art." Contribution to the exhibition catalogue for ART/artifact. New York: Center for African Art, 1988.

Dutton, Denis. "Tribal Art and Artifact." The Journal of Aesthetics and Art. Criticism 51, no. 1 (Winter 1993), 13-21.

Dussart, Francoise. "Translacje malowidła na ciele" ("Translation of paintings on the body"). In Estetyka Aborygenów. Antologia (Aesthetics of Aborigines. Anthology), edited by Monika Bakke. Kraków: Universitas, 2004.

Farr, Francine. "The Art of Aboriginal Australia." African Arts 22, no. 3 (May, 1989), 84-85.

Francesca, Pierro della. De prospectiva pingendi. O perspektywie w malarstwie (De

48. Coleman, "Appreciating 'Traditional' Aboriginal Painting Aesthetically," 237. 
Vol. 6, No. $4 \quad$ Alcaraz: Contemporary Aboriginal Art from Australia's Desert...

prospectiva pingendi. About the perspective in painting), edited by Ryszard Mirek. Kraków: Universitas, 2016.

Glowaczewski, Barbara. "Dynamic Cosmologies and Aboriginal Heritage." Anthropology Today 15, no. 1 (February 1999), 3-9.

Ingarden, Roman. Studia z estetyki 1 (Studies in aesthetics 1). Warsaw: PWN, 1957.

Larson, Kay. "Their Brilliant Careers." New York Magazine (4 October 1988), 148150.

Lukaszewicz Alcaraz, Aleksandra. "Can We Talk about Contemporary Avantgarde outside Western Cultures? The Case of Contemporary Art in the Republic of South Africa." Art Inquiry. Recherchers sur les arts 19, no. 28 (2017), 171-185.

Margolis, Joseph. The Arts and the Definition of the Human: Toward a Philosophical Anthropology. Stanford: Stanford University Press, 2008.

- What, After All, Is a Work of Art?: Lectures in the Philosophy of Art. University Park: Pennsylvania State University Press, 1999.

_. "Farewell to Danto and Goodman." British Journal of Aesthetics 38, no. 4 (October 1988), 369.

_. "Intentionality, Institutions, and Human Nature." The Monist 69, no. 4 (October 1986), 546-567.

_. "Works of Art as Physically Embodied and Culturally Emergent Entities." The British Journal of Aesthetics 14, no. 3 (1 March 1974), 187-196.

Morphy, Howard. "Encoding the Dreaming - A Theoretical Framework from the Analysis of Representational Processes in Australian Aboriginal Art." Australian Archaeology no. 49 (December, 1999), 12-22.

_. "On representation of ancestral beings." In Animals into Art, edited by Howard Morphy, 144-160. London: Unwin/Hyman, 1998.

Ancestral Connections: Art and an Aboriginal system of knowledge. Chicago: University of Chicago Press, 1991.

Persson, Beatrice. In-Between: Contemporary Art in Australia. Cross-culture, Contemporaneity, Globalization. Goteborg: Goteborg Acta Universitatis Gothoburgensis, 2011.

Pizzi, Gabriele. "Contemporary Aboriginal Desert Paintings." In Catalogue for the exhibition shown at the Plimsoll Gallery, Painting from the desert. Contemporary Aboriginal paintings. Tasmania: University of Tasmania, Centre for the Arts, 1990.

Watson, Christine. "Dotykając ziemi. Ku estetyce współczesnego malarstwa Balgo" ("Touching the earth, towards the aesthetics of contemporary Balgo painting"). In Estetyka Aborygenow. Antologia (Aboriginal aesthetics. Anthology), edited by Monika Bakke. Kraków: Universitas, 2004. 